\title{
How to Keep Deep-Sea Animals
}

\author{
Hiroshi Miyake1,2,3, Mitsugu Kitada², Dhugal J. Lindsay³, \\ Toshishige Itoh ${ }^{2}$, Suguru Nemoto ${ }^{2}$ and Tetsuya Miwa ${ }^{3}$ \\ ${ }^{1}$ Kitasato University, \\ ${ }^{2}$ Enoshima Aquarium, \\ 3JAMSTEC \\ Japan
}

\section{Introduction}

The ocean covers $71 \%$ of the surface of the Earth. The deepest trench is the Mariana Trench, with a depth of $11000 \mathrm{~m}$. The average elevation of terrestrial areas is about $840 \mathrm{~m}$ high, while the average depth of the oceans is about $3800 \mathrm{~m}$. This means that the average elevation above the rock substrate for the Earth is $-2440 \mathrm{~m}$ - i.e. within the seas. Moreover the volume of the ocean is 300 times the volume of all terrestrial areas combined. The coastal area of the ocean is less than $10 \%$ of the total area of the oceans. The deep sea lies under the epipelagic zone, which is the layer from the surface to $200 \mathrm{~m}$ depth. The volume of the deep sea is over $95 \%$ of the total volume of the oceans. The deep-sea realm is the largest biosphere on the Earth. There are three categories of habitat in the deep-sea realm. One is the deep-sea floor, the second is the bentho-pelagic layer, which is the layer from the deep-sea floor up to an altitude above the bottom of $100 \mathrm{~m}$, and the third is the mid-water zone, which is between the epipelagic layer and the bentho-pelagic layer. The mid-water is an extremely important realm, and holds the key to elucidate the cycles of matter in the ocean, carbon transportation from the surface layer to the deep sea, and the interaction between the behavior of oceanic circulation with global warming and the lives of deep-sea animals. However, information about mid-water biology is extremely limited because of the difficulty of sampling swimming (nekton) and floating (plankton) animals in the mid-water. The mid-water community is one of the most mysterious of all deep-sea communities.

The deep sea is a mysterious kind of Inner Space for us, even though the ocean is closer than Outer Space. High water pressure in the deep sea keeps us from easily exploring this realm. Studies of deep-sea animals have long been carried out through net sampling using tools such as dredges, trawl nets, plankton nets and line fishing. However, the development of deep-sea crewed submersibles and remotely-operated vehicles (ROVs) has drastically changed the way we study deep-sea biology. These deep-sea survey tools allow us to visit places where fishing nets cannot trawl, e.g. deep-sea valleys, outcrops of base rocks, cliffs, gaps, hydrothermal vent areas and cold seep areas. Moreover, they allow us to observe deep-sea animals and their behavior in-situ. This is particularly true of gelatinous zooplankton, which are vastly understudied because their fragile bodies are easily damaged and destroyed by fishing nets. Crewed submersibles and ROVs have enabled rapid progress 
in the study of gelatinous zooplankton because they allow us to observe their behavior and collect them in pristine condition (Miyake et al., 2001; Robison, 2004).

The most history-changing moment for deep-sea biology is undoubtedly the discovery of a deep-sea chemosynthetic ecosystem off the Galapagos Islands in 1977 (Corliss \& Ballard, 1977; Corliss et al., 1979). This discovery is widely considered to be one of the greatest discoveries of the $20^{\text {th }}$ century. Hydrothermal vents can spew hot water at temperatures above $300{ }^{\circ} \mathrm{C}$ at 2600 $\mathrm{m}$ depth. Many animals live around hydrothermal vents and most of the animals do not depend on solar energy like we do, but on heat and chemical energy from inside the Earth. Hydrothermal vent fluids can include hydrogen sulfide and methane from deep within the Earth. Bacteria use these chemicals for chemosynthesis - the making of organic molecules using chemical energy. Primary production in deep-sea chemosynthetic ecosystems relies on chemosynthetic bacteria rather than the photosynthesis of plants. Seven years after the discovery of the first hydrothermal vent, a cold seep was discovered off the coast of Florida in the Gulf of Mexico (Paull et al., 1984). Cold seeps are often located on the seafloor close to faults or the margins of oceanic plates. Chemosynthesis-based associations also occur at cold seeps. After the discovery of hydrothermal vents and cold seeps, the first whale fall community was discovered in the Santa Catalina Basin in 1987 (Smith et al., 1989). Many animals that were related to animals from hydrothermal vents and cold seeps were discovered there. Dead whales sink to the deep-sea floor and are eaten by animals such as sharks, hagfish, crabs, and so on. Remnants of the whale carcass then remain on the deep-sea floor, still containing abundant organic matter such as blubber and bone marrow. Rotten fat promotes the formation of hydrogen sulfide and methane. Therefore many animals that are related to animals from hydrothermal vents and cold seeps are able to inhabit such whale carcasses.

The study of deep-sea biology has progressed rapidly since deep-sea submersibles began to be used for science (Gage \& Tyler, 1991; Van Dover, 2000; Herring, 2002; Fujikura et al., 2008). However, many aspects of deep-sea biology still need to be investigated. Surveys using deep-sea submersibles can obtain data on behavior, systematics, evolution, symbioses, and biodiversity, using video images, samples preserved using chemicals, and frozen samples. It is now possible to observe deep-sea animals in situ with the naked eye or with HDTV cameras. Many questions have arisen from such real time observations of deep-sea animals. However, it is difficult to observe deep-sea animals over the long term in situ. Our observations of deep-sea animals using these tools are limited to only a few points during the space-time of their lives. One method to connect these points over time is the rearing and observation of deep-sea animals. One of the next important and necessary steps in deep-sea biology is to study live deep-sea animals in land-based aquaria using rearing and observation methods. The keeping of deep-sea animals has been tried in many institutes and public aquaria around the world because the rearing of deep-sea animals is considered by many to be an essential development for the future. In this chapter, we would like to introduce methods for the collection and maintenance of deep-sea animals, especially midwater animals and chemosynthetic ecosystem-associated animals.

\section{Environment of the deep sea}

The deep sea is a realm of darkness, cold, and high water pressure. Water temperature and salinity of the surface water layer vary from one locality to another according to season, latitude, or ocean currents. However, the differences in water temperature and salinity are 
smaller at $600 \sim 800 \mathrm{~m}$ depths. At these depths the water temperature and salinity is about 4 ${ }^{\circ} \mathrm{C}$ and 34.5 respectively in almost all ocean areas. The dissolved oxygen concentration is at its lowest at these depths - around $1.0 \mathrm{ml} / 1$ off Japan and $0.1 \mathrm{ml} / 1$ off the south-west coast of the U.S.A. As for sunlight, only blue light can penetrate to $1000 \mathrm{~m}$ depth. There is no red light penetrating from the surface to these depths.

The environment at deep-sea chemosynthesis-based ecosystems is very different from the normal deep-sea environment. Hydrothermal vent areas are extremely different, with the temperature of the hot water being $100 \sim 300{ }^{\circ} \mathrm{C}$. This hot water has a high chemical activity, containing high concentrations of minerals and volcanic gases from under the sea floor. This water is a reductive environment with no dissolved oxygen, high concentrations of hydrogen sulfide and carbon dioxide, low $\mathrm{pH}$ and containing many minerals. On the other hand, the ambient water around hydrothermal vents is normal, cold deep-sea water. Minerals dissolved in the hot water recrystallize to form chimneys when the hot water comes into contact with the cold ambient water. The low density hot water ascends quickly into the water column and mixes with ambient water. When the density of the mixed water becomes the same as the ambient water, the mixed water stops its ascent and spreads out horizontally. This water mass is called a hydrothermal plume. This environment of high hydrogen sulfide, low oxygen, high carbon dioxide and low $\mathrm{pH}$ is in direct contrast to the normal environment we regularly use for rearing aquatic animals. Hydrothermal vent animals live in a drastic environmental gradient with temperatures from below $4{ }^{\circ} \mathrm{C}$ to over $100{ }^{\circ} \mathrm{C}$, both reductive and oxidative environments, and from acid to alkaline water. On the other hand, at cold seeps, hydrogen sulfide and methane seep slowly from the sea floor.

\section{Sampling}

Sampling of mid-water animals has been carried out using plankton nets such as the IKMT (Issacs-Kidd Mid-water Trawl), a multiple opening/closing net called the IONESS (Intelligent Operative Net Sampling System), and deep-sea submersibles and ROVs (Fig. 1). There are advantages and disadvantages to all of these sampling methods for obtaining mid-water animals. Plankton nets can collect many species and large numbers of mid-water animals, however, the animals collected in the net are usually damaged because they are buffeted around in the net during towing. Animals are also weakened by being exposed to

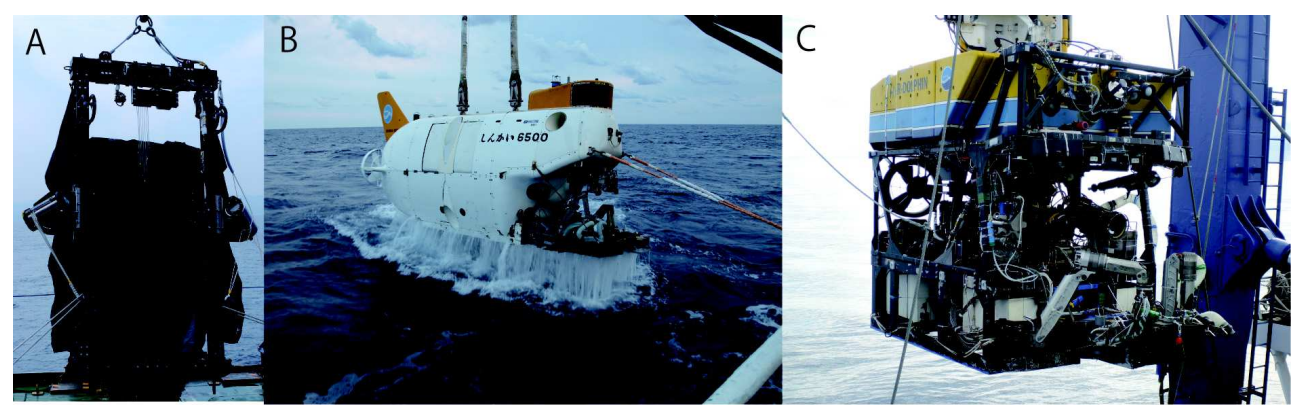

Fig. 1. Sampling gears of deep-sea animals. A: IONESS, B: HOV Shinkai 6500, C: ROV Hyper-Dolphin 
the higher temperatures of surface waters during retrieval of the nets. To minimize these disadvantages, the duration of the tow must be as short as possible, and sampling is best done in the winter season when surface water temperatures are low.

On the other hand, deep-sea submersibles and ROVs can sample mid-water animals individually in pristine condition using slurp-gun systems, gate valve samplers, and detritus samplers (Hashimoto et al., 1992; Hunt et al., 1997). However, the number of animals able to be sampled during a single dive using present systems is at most ten or so. Plankton nets are better suited for sampling animals that swim fast and have hard bodies, such as fish and shrimp, but submersibles are better suited for sampling animals that swim slowly and have fragile bodies, such as jellyfish.

As for organisms from deep-sea chemosynthesis-based communities, deep-sea submersibles and ROVs equipped with slurp-gun systems, sample boxes, scoops or MT core samplers are used (Miyake et al., 2005).

The most important point for successfully sampling deep-sea animals to keep in an aquarium is to collect them in the best condition possible. It is essential to collect animals with minimal external wounds and to keep water temperature in the sample box or canister low. Water temperature for maintenance of deep-sea animals should be about $4{ }^{\circ} \mathrm{C}$, but the surface water temperature off Okinawa, Japan, in summer can be over $28^{\circ} \mathrm{C}$. This high temperature is fatal for deep-sea animals. To keep temperature changes to a minimum, we use a large slurp gun canister that can hold a large volume of sea water at the ambient temperatures at which the deep-sea animals live. As for the collection of animals from the deep-sea floor, for example the giant white clam Calyptogena, we collect them with a scoop and place them in a sample box topped up with mud from their habitat in order to minimize the influence of warm surface waters during submersible or ROV recovery.

The next point is correct treatment of animals after retrieval to the deck of the ship. When the animals come on deck, they are quickly transferred into buckets filled with seawater at temperatures adjusted to the same temperature as their habitats $\left(4 \sim 16^{\circ} \mathrm{C}\right)$. Animals are then transferred into rearing tanks set up in special cold-rooms on deck. Some deep-sea animals may be weakened greatly or seem to be in a moribund condition, however, these weakened animals sometimes recover in cold water aquaria overnight.

When deep-sea animals are brought to the surface, the water pressure is, as a rule, not kept at ambient deep-sea pressures, but water temperature is maintained as far as possible. The animals introduced above are usually able to endure the change of pressure between the deep-sea and the surface. We use the DEEP AQUARIUM for animals that need to be kept at deep-sea pressures for survival during retrieval (Koyama et al., 2002). The sphere of the DEEP AQUARIUM is connected to the slurp-gun set on submersibles, and animals are sucked into the sphere before the lid being closed and pressure maintained at the ambient levels. Upon retrieval the sphere is attached to the life-support system for the DEEP AQUARIUM that controls pressure, dissolved oxygen and has a filtration system for recycling the water in the sphere. The DEEP AQUARIUM is also used as a pressure chamber for animals that have been weakened by decompression sickness.

After cruises, deep-sea animals are usually transferred to the Enoshima Aquarium, to the Japan Agency for Marine-Earth Science and Technology (JAMSTEC), or to Kitasato 
University in cold storage by airplane and/or by truck within 48 hours. Most animals are transported to their destinations within 36 hours.

\section{Mid-water and bentho-pelagic animals}

The mid-water is characterized by having no ceiling and no floor. Mid-water animals must remain suspended by floating or swimming at all times to maintain their depth positions in the mid-water. This is the most important factor to remember when trying to keep them in an aquarium.

To keep mid-water and bentho-pelagic animals, we use planktonkreisels (Hamner, 1990; Raskoff et al., 2003; Widmer, 2008) and a jellyfish tank that was developed by Kamo Aquarium, Japan (Fig. 2).

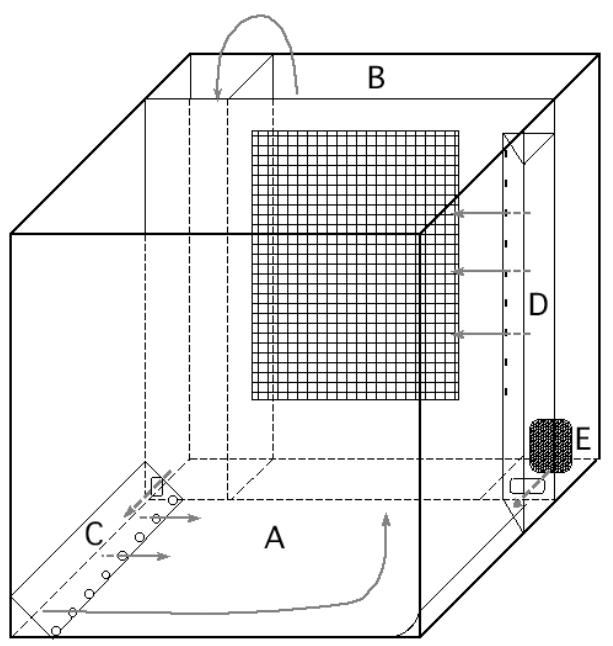

Fig. 2. Rearing tank for jellies. A: Rearing space. B: Filtration area. C: water outlet area, designed to produce currents in the rearing area. D: water outlet area, designed to produce currents to keep jellies off the filter mesh. E: Submersible pump.

The jellyfish tank is a simple box tank that makes a slow, gentle current for jellies using differences in water level. Temperature, salinity and dissolved oxygen are controlled to conform to the habitat data recorded by the CTD-DO meter deployed on the submersible or ROV. In particular, dissolved oxygen in the deep sea is lower than in surface waters. Dissolved oxygen in land-base aquaria is very high compared to the levels that mid-water animals usually encounter and such high concentrations of oxygen may damage them. When mid-water animals show oxyecoia intoxication, dissolved oxygen is regulated to low concentrations by bubbling nitrogen gas using a Dissolved Oxygen Concentration Control System (DOCCS) (Fig. 3) (Miyake et al., 2006). 


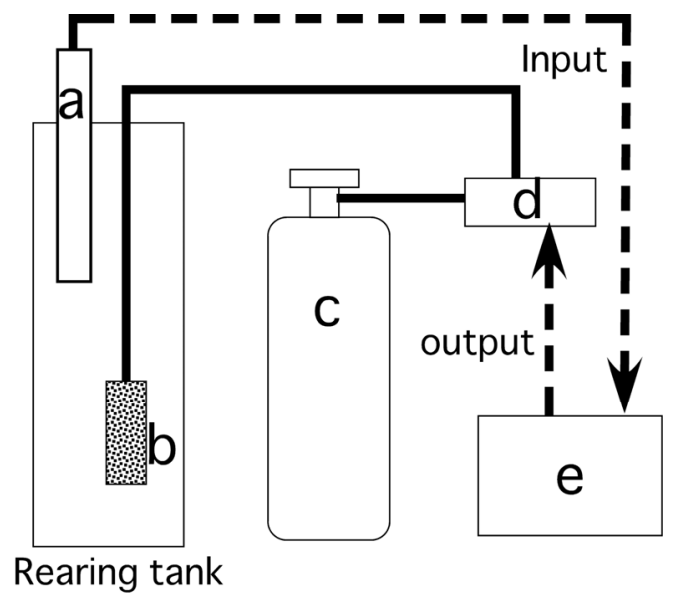

Fig. 3. Dissolved Oxygen Concentration Control System (DOCCS) a: DO sensor, b: Air stone, c: Nitrogen tank, d: Electromagnetic valve, e: Control unit DO electric value which is measured at DO sensor (a) is processed by control unit (e). When DO value is higher than preset DO value, the control unit send a signal to electromagnetic valve (d) to open the valve, and nitrogen gas added to the aquarium. When DO reaches to the preset value, the electromagnetic valve is closed and nitrogen input stops.

Sometime an ultraviolet lamp is installed at the outlet of the filtration tank, because the midwater generally has low abundances of bacteria. As for lighting, no statistically-proven, quantitative data exists, but experience suggests that lighting affects the survival of deep-sea animals in aquaria. Strong white light can make deep-sea animals blind (Herring et al., 1999). Some pigments of deep-sea animals such as porphyrin-derivatives can turn toxic when exposed to light (Herring, 1972). At public aquaria, artificial lighting such as by white fluorescent lamps or halogen lamps, as well as exposure to daylight over long periods, can lead to early death of deep-sea animals. We use red LED lamps to decrease mortality. An added advantage is that deep-sea animals show natural behaviors under red LED light.

\subsection{Gelatinous zooplankton}

Observations and experiments on live jellyfishes are necessary to understand their life history strategies in the deep sea. Therefore establishment of how to collect and keep jellyfishes that inhabit the mid-water and benthopelagic zones is necessary. However, it is difficult to collect many individuals of one species of jellyfish during a deep-sea dive. Jellyfishes have complex life cycles, including alternation of generations between a planktonic medusa stage (sexual generation), and a benthic polyp stage (asexual generation). This polyp stage has a great ability to regenerate. If we can collect a deep-sea polyp that also has a medusa generation, we can raise medusae from the polyp. The collection of polyps from the deep-sea in order to raise and keep deep-sea jellyfish in the aquarium is a very useful method.

We collect hard-bodied benthos like snails, as well as other substrates such as sunken wood, rocks and deep-sea litter, in order to find polyps. We also deploy and recover pot-plant pots 
with marker buoys on the deep-sea floor using manned submersibles and ROVs. Some polyps of hydrozoans and scyphozoans were successfully collected on these substrates and were subsequently kept in aquaria with temperatures regulated to the same temperature as their in situ habitats $\left(4 \sim 12{ }^{\circ} \mathrm{C}\right)$ and at atmospheric pressure. These polyps were kept in small aquaria $(30 \mathrm{~cm}-20 \mathrm{~cm}-25 \mathrm{~cm} \mathrm{H})$ with a sponge filter and fed Artemia nauplii twice a week. Every species of polyp formed a colony on the substrates through asexual reproduction. Some polyps in the colony were collected using a needle under a stereoscopic microscope and transferred into a petri-dish $(\varphi 80 \mathrm{~mm}-4 \mathrm{~cm} \mathrm{H})$. After the polyps attached to the bottom of the petri-dish, Artemia nauplii were fed to them twice a week. About four hours after feeding, each time, all the rearing water was changed. Using this method, we have been able to observe the growth, degrowth, regeneration, colony formation, medusa bud formation, and strobilation of polyps in the laboratory.

The hydroid from a Ptilocodium sp. was collected on a pot-plant pot with marker buoy deployed at a depth of 1170m off Hatsushima Island, Sagami Bay (Fig. 4). This species attached to the pot-plant pot substrate itself rather than to the rope or marker. There were two types of polyp in the colony - gastrozooids and dactylozooids. Dactylozooids had four tentacles and lacked mouths. Gastrozooids ate food that the dactylozooids caught with their tentacles. One to four medusa buds were formed on the basal part of gastrozooids. Medusae just after liberation had four short tentacles. This species was kept successfully at $4{ }^{\circ} \mathrm{C}$ and was unable to be kept at temperatures above $10^{\circ} \mathrm{C}$.
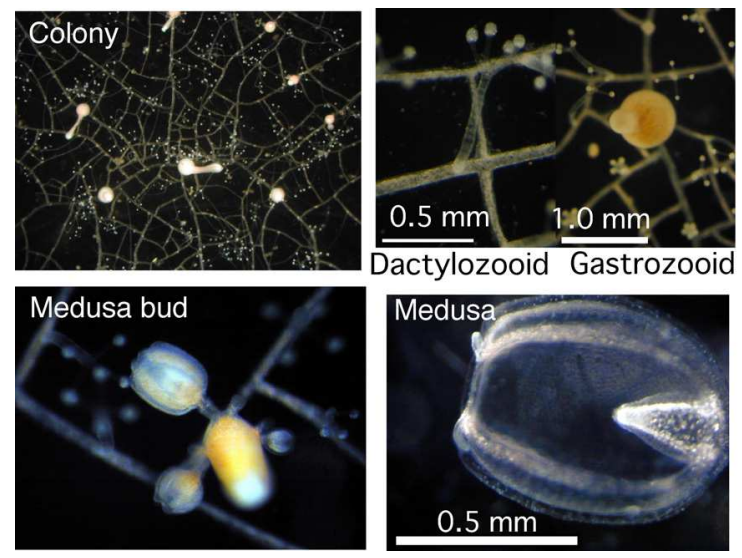

Fig. 4. Ptilocodium sp.

A large species of hydrozoa, Corymorpha sp., was collected using a suction sampler at a depth of 530m off Mera, Suruga Bay (Fig. 5a). This species inhabits sandy substrates. Just after sampling, this specimen was $15 \mathrm{~cm}$ in height and was composed of a long hydrocaulus and a terminal hydranth. Five polyps were found at the base of the hydrocaulus. The number of aboral tentacles was about 60 and the number of oral tentacles was about 50 . Blastostyles were located just above the aboral tentacles of the hydranth and had many medusa buds (Fig. 5b). Some medusae were liberated from the blastostyles (Fig. 5c). After sampling, all tentacles on the hydranth become atrophied and the hydranth dropped off from the hydrocaulus. The remaining hydrocaulus degenerated into a tissue mass. The 
tissue mass regenerated into a polyp after one month and started asexual reproduction(Fig. 5d). The liberated hydranth also regenerated tentacles and caught Artemia nauplii. One polyp degenerated into a tissue mass and was divided into two separate tissue masses. Each of these tissue masses regenerated into a new individual. Lighting had a detrimental effect on this species during rearing, causing atrophication of tentacles and degeneration into a tissue mass.

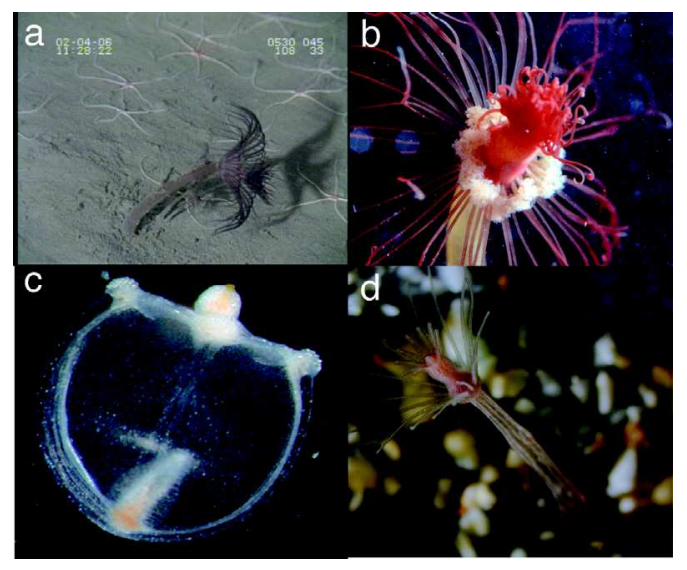

Fig. 5. Corymorpha sp.

It is necessary to rear the medusae that are released from such polyps until they are fully grown in order to clarify the life history of the species. Recently, some studies have been published about the life cycles and new species descriptions of deep-sea jellies from Monterey Bay (Widmer, 2007; Widmer et al., 2010; Widmer, 2011). Keeping deep-sea jellyfish in the laboratory makes it much easier to obtain detailed data about them that we would be unable to obtain in situ.

\subsection{Mid-water shrimp, Bentheogennema borealis}

Bentheogennema borealis is a mid-water shrimp referred to as Shinkai Ebi in Japanese (Shinkai means deep-sea and Ebi means shrimp in Japanese). This species is colored deepred (Fig. 6). Sampling was done using a multiple opening/closing net - the IONESS (Intelligent Operative Net Sampling System). Many B. borealis were collected from $600 \mathrm{~m}$ to $1500 \mathrm{~m}$ depths in Sagami Bay, Japan. However, more than half of the shrimps were dead when the IONESS was retrieved onto the deck. To increase the survival rate when rearing the shrimp, it is essential to sample them in the winter season when surface water temperature is low. Lively shrimps were selected from the collected animals and transferred into buckets filled with chilled water $\left(4^{\circ} \mathrm{C}\right)$. Selected shrimps were kept in the aquaria that were developed for jellyfish rearing (outlined above) at $4^{\circ} \mathrm{C}$. Most of the shrimps had damaged antennae and could not swim normally but instead spiraled as they swam. Weakened individuals did not show any escape response. Such individuals must be eliminated from the rearing tank before the water becomes clouded and water quality worsens due to the fats and oils exuded from weakened individuals. When water became 
clouded, it was exchanged with fresh sea water. White light was also considered not to be good for them so red LED lights were used for observation. They could not catch food by themselves because of the damage incurred during sampling. Therefore, we fed them a piece of krill or mysid meat directly to the mouth of each individual. The survival rate was about $11 \%$ for the first month, and about $6 \%$ over three months. Maximum duration of survival was more than 575 days. Some individuals molted and regenerated antennae and/or legs.

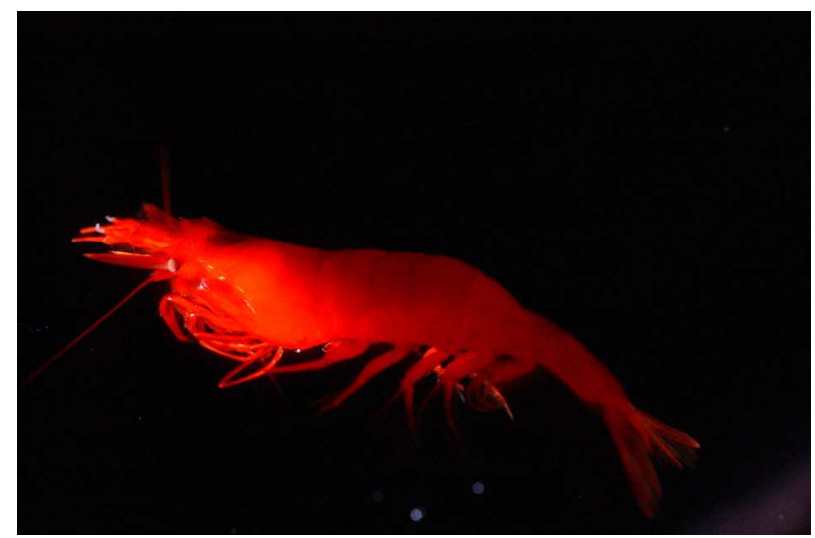

Fig. 6. Bentheogennema borealis

\section{Chemosynthesis-based ecosystem animals}

Deep-sea biologists can observe and collect live animals from deep-sea chemosynthetic ecosystems using ROVs or manned submersibles. However, it has been difficult to keep them alive over the long-term in order to perform a large variety of biological studies. Keeping deep-sea animals from chemosynthetic ecosystems in captivity enables many useful studies of these animals, as researchers can conduct experiments at any time, without needing to participate in deep-sea diving cruises. Keeping these animals is also very useful for public aquaria or science museums as part of a deep-sea biology outreach program to the public.

The rearing of animals from deep-sea chemosynthesis-based ecosystems has been difficult due to problems in maintaining high pressure, low $\mathrm{pH}$, optimizing $\mathrm{H}_{2} \mathrm{~S}$ and high $\mathrm{CO}_{2}$ concentrations, low dissolved oxygen, and keeping low light and low temperature conditions. These conditions are far removed from the normal rearing conditions for most fishes in aquaria. To overcome these problems, artificial hydrothermal vent tank and cold seep system tanks have been developed (Miyake et al., 2006; Miyake et al., 2007) (Fig. 7). 

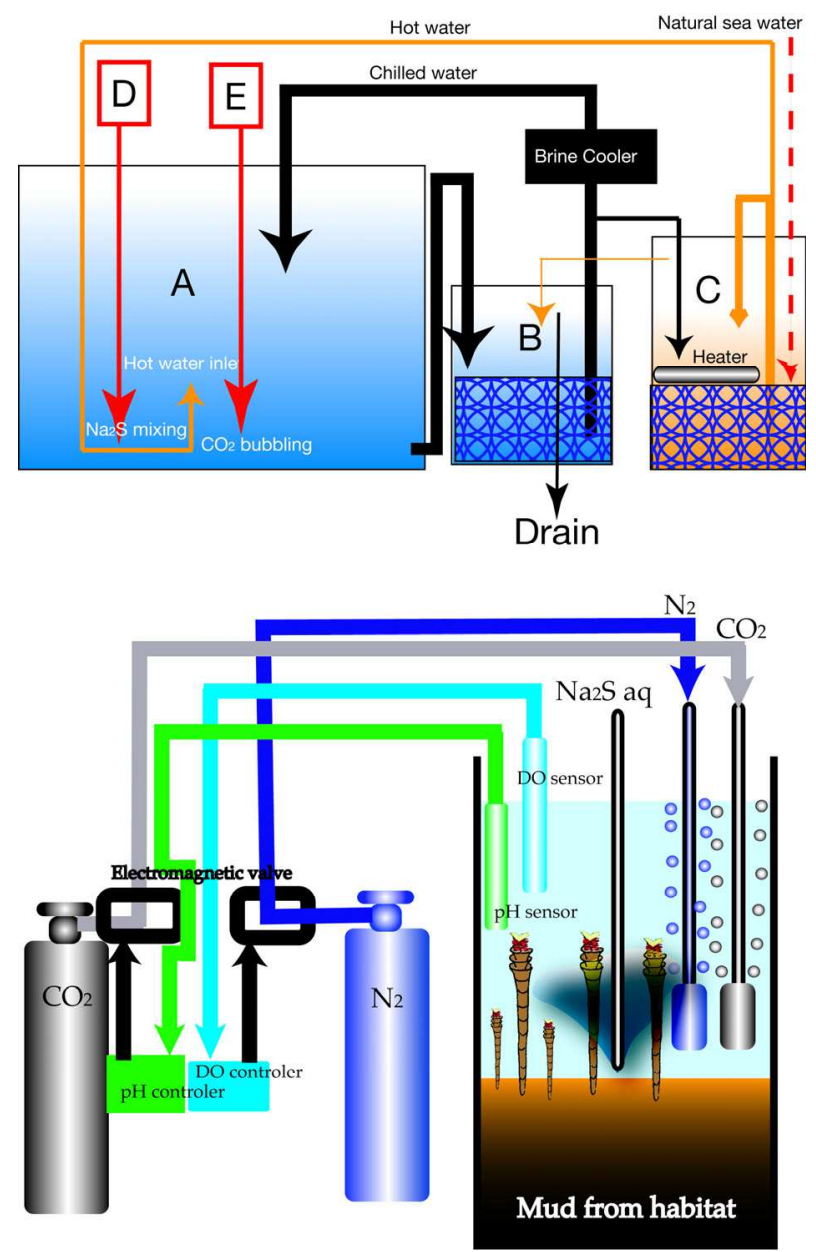

Fig. 7. Artificial hydrothermal vent and cold seep systems

Upper: Artificial hydrothermal vent system. A: Main rearing tank. Temperatures were $12{ }^{\circ} \mathrm{C}$ and $4{ }^{\circ} \mathrm{C}$. B: Filtration tank. Filtration material was coral sand. C: Heating tank. Heating tank was also for filtration. D: Sodium sulphide tank. E: $\mathrm{CO}_{2}$ cylinder.

Lower: Artificial cold seep systems

In 2006, the Deep-sea Chemosynthetic Ecosystem Tank (Fig. 8), with an artificial hydrothermal vent and cold seep system, was opened in the Deep-sea Corner at Enoshima Aquarium. This tank (3000WX1000-1500HX1000D (mm)) consists of three parts, a hydrothermal vent area, a cold seep area and a whale fall area. In the whale fall area, bones of a whale are displayed. In the cold seep area, the reduction zone is made using $30 \mathrm{~cm}$ of mud mixed with decaying organic matter. The system of the tank is composed of a heating tank, a hot water outlet with added $\mathrm{Na}_{2} \mathrm{~S}$ as a source of $\mathrm{H}_{2} \mathrm{~S}$, and added $\mathrm{CO}_{2}$ for chemosynthetic bacteria and $\mathrm{pH}$ regulation. When the need arises, a DO control unit (DOCCS) is attached. There are some artificial chimneys, which act as hot water vents. The 
maximum temperature of hot water is $60^{\circ} \mathrm{C}$. Ambient water is 2 to $6^{\circ} \mathrm{C}$, with an average temperature of $4^{\circ} \mathrm{C}$.

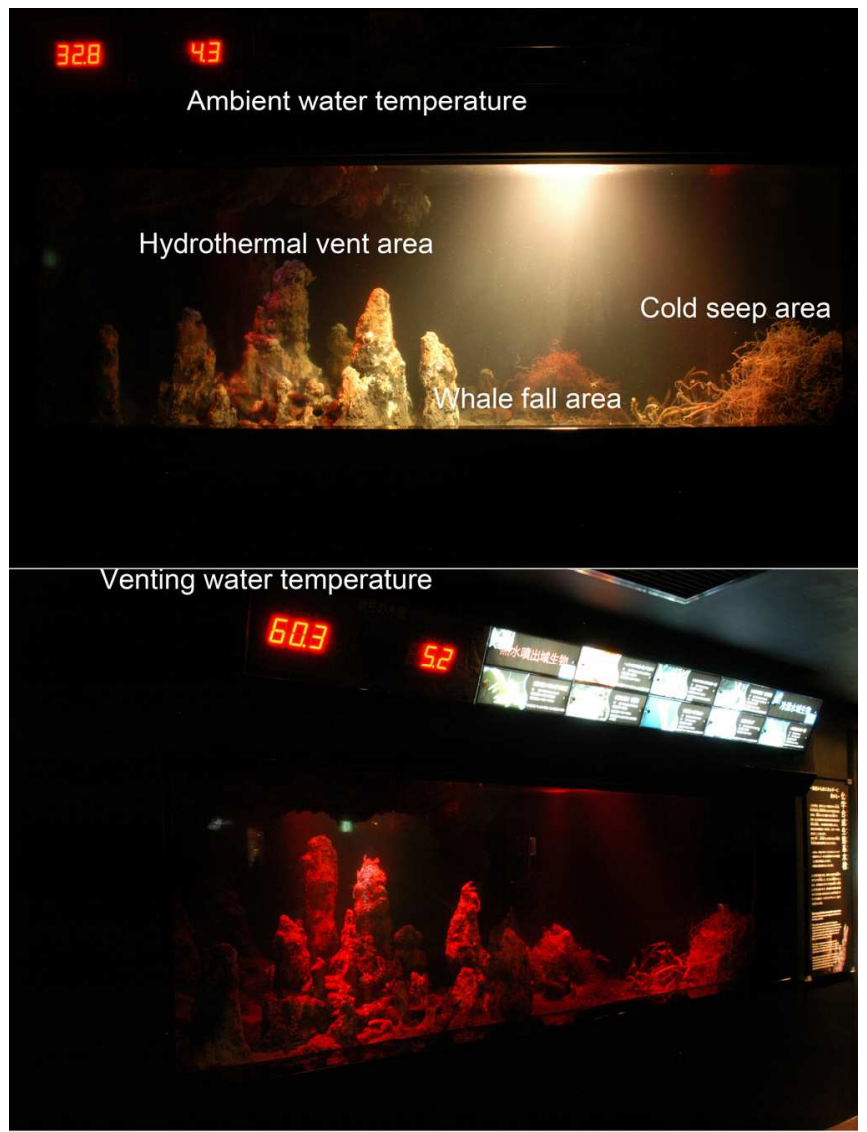

Fig. 8. The Deep-sea Chemosynthetic Ecosystem Tank, the main tank in the Deep-sea Corner in Enoshima Aquarium. Upper: Front view of the tank. Hydrothermal vent area venting hot water from imitation chimneys is located on the left side of the tank. Cold seep area is located at the right side of the tank. Whale fall area includes whale bone collected from Sagami Bay (924m). Two temperature signs (red) are displayed, the left sign is the hot water temperature, and the right sign is ambient water temperature. Below: Lighting is always red light. Hot water from imitation chimney is a maximun of $60^{\circ} \mathrm{C}$.

\subsection{Hydrothermal vent crabs and shrimps (Fig. 9)}

Hydrothermal vent crabs, Gandalfus yunohana, Austinograea alayseae, A. rodriguezensis and the vent shimps, Alvinocaris longirostris, Opaepele loihi and Opaepele spp. have been kept in the hydrothermal vent system tank. Alvinocaris longirostris did not show any tendency to keep close to hot water vents, while the others have a strong tendency to keep close to hot water vents and gather around the outlet for hot water. Survival rates of these animals, except for 
A. longirostris, were higher in the tank with hot water vents than in a tank without any hot water vents. Experience shows that white lighting was not good for the animals, with white light sometimes killing them, but red LEDs were a good source of illumination. They are fed krill, mysid or fish meat twice a week.

The vent crab G. yunohana exhibits behavior where females are guarded by the males before they molt. After molting, copulation has been observed. On the other hand, males just after molting are often cannibalized by other individuals in the aquarium. Some females spawned in the rearing tank. Gravid crabs maintained eggs on their abdomen in the hot water vent. Some eggs collected from females were kept in petri dishes with controlled temperatures at $12^{\circ} \mathrm{C}$ and $20^{\circ} \mathrm{C} .12^{\circ} \mathrm{C}$ is the ambient water temperature in the rearing tank. Larvae hatched at $20^{\circ} \mathrm{C}$, but did not hatch at $12^{\circ} \mathrm{C}$. Adult crabs have no eyes, however hatched larvae have eyes. Unfortunately, rearing of the larvae has not yet been successful.

The vent shrimp graze on filaments and mats of chemosynthetic bacteria attached around the inlets for hot water, as well as eating krill, mysid or fish meat. O. loihi was brooding eggs when collected from the field and continued to brood them in the tank. Adult shrimps have no eyes, but larvae have eyes and were observed to swim upward in an upside-down posture. However, rearing of these larvae has not yet been successful.

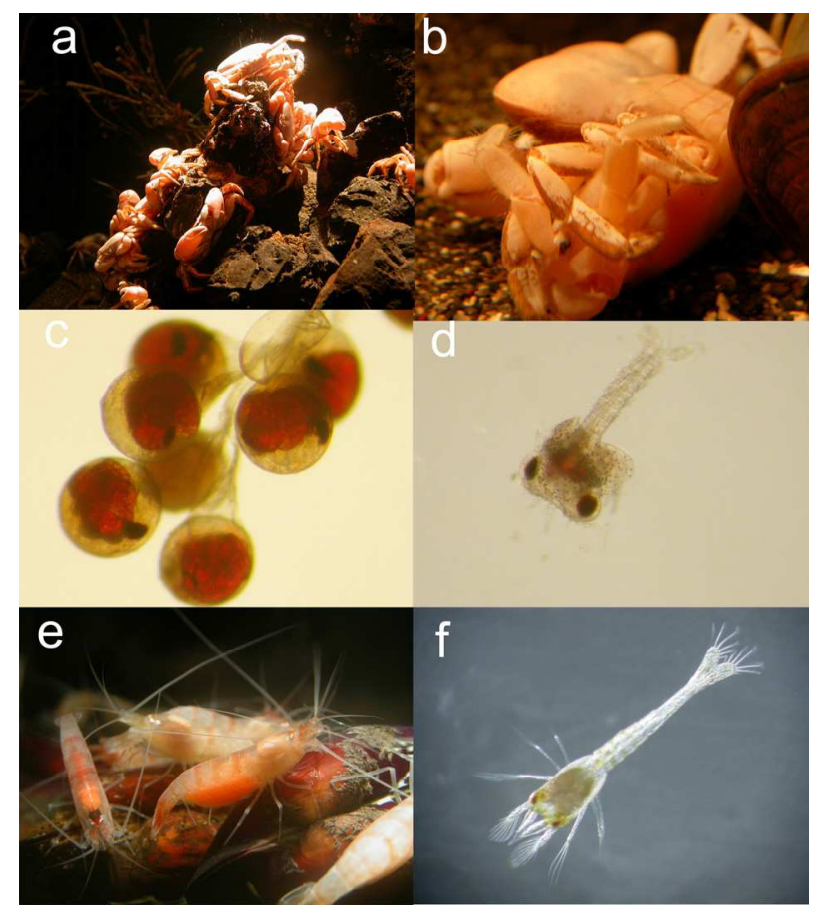

Fig. 9. Behaviors and breeding of vent crab and shrimp in the aquarium.

a: Gandalfus yunohana gathered around artificial hydrothermal vent, b: mating behavior of $G$. yunohana, c: eyed eggs of G. yunohana, d: hatched larva of G. yunohana, e: gravid female of Opaepele loihi, f: hatched larvae of O. loihi 


\subsection{Hydrothermal vent squat lobsters}

The hydrothermal vent-associated squat lobster Shinkaia crosnieri was collected at a hydrothermal vent area at depths of $1000 \sim 1600 \mathrm{~m}$ in the Okinawa Trough (Fig. 10a). S. crosnieri has a unique feeding ecology. This species has bushy white hairs, upon which dense chemosynthetic bacterial filaments are attached, on its ventral side (Fig. 10b). This species does not eat normal foods such as krill, mysid or fish meat, but instead grazes on the bacterial filaments on its bushy ventral hairs. This species lives near hydrothermal vents and farms chemosynthetic bacteria on its bushy ventral hairs. S. crosnieri has been kept in the vent system tank, but it showed no tendency to remain close to the hot water vent inlets like vent crabs do. Suitable rearing temperatures were $4 \sim 7^{\circ} \mathrm{C}$, and temperatures less than $3^{\circ} \mathrm{C}$ or more than $10^{\circ} \mathrm{C}$ were not suitable for long-term rearing.

S. crosnieri had bushy white hair with dense bacterial filaments attached at the time of sampling. However, a few days after sampling these dense bacterial filaments had disappeared from animals kept in a normal non-vent environment-simulating tank. In hydrothermal vent system tanks, bacterial filaments on the white hairs on the ventral side of S. crosnieri increased in bushiness within a few days. It has been observed that S. crosnieri graze on these bacteria using their mouthparts. A combination of optimum hydrogen sulfide concentrations and jetting water stream speed may be a key to emulating their in situ environment. A single molting was observed. The individual had no bacterial filaments on its ventral hairs after molting and died about one month later.

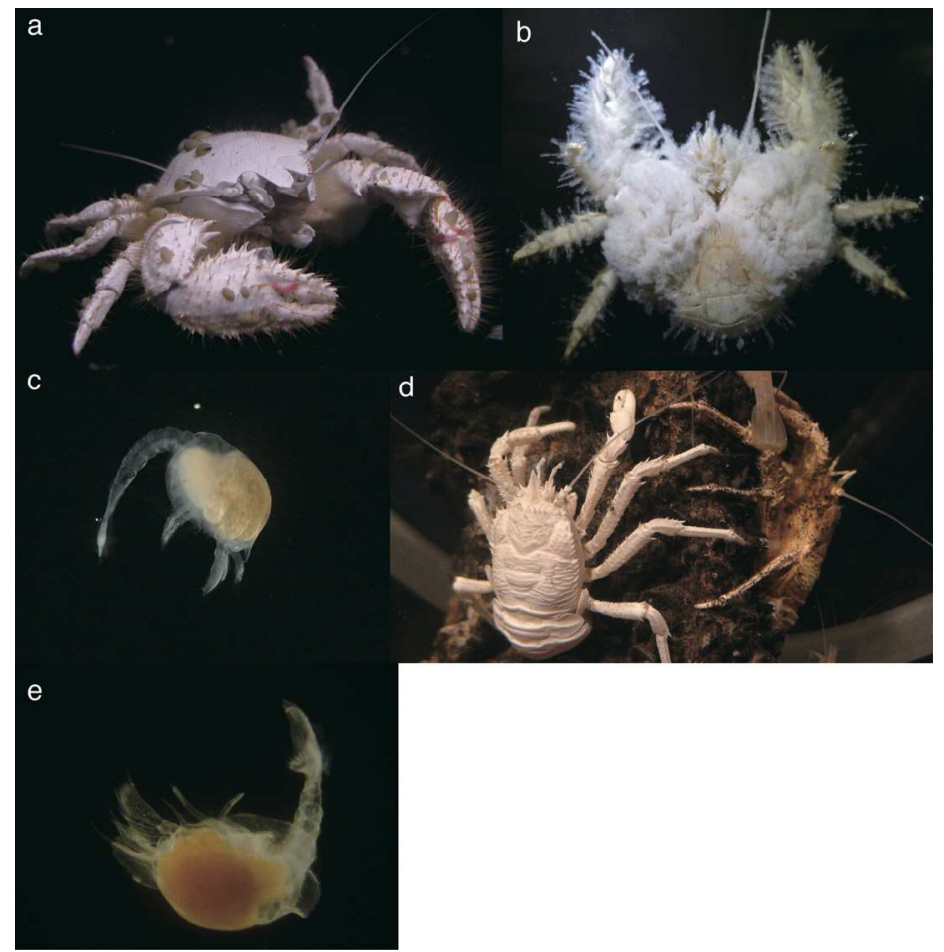

Fig. 10. Shinkaia crosnieri $(\mathrm{a} \sim \mathrm{c})$ and Munidopsis myojinensis $(\mathrm{d} \sim \mathrm{e})$ 
Some specimens were brooding eggs when they were collected and continued brooding eggs in the vent tank. Eggs were attached to the pleopods of the females. The color of the eggs was white, and they were approximately $2 \mathrm{~mm}$ in diameter. The eggs of some individuals hatched (Fig. 10c). Larvae were positively buoyant and remained at the water surface without sinking. Adult individuals have no eyes, however hatched larvae had eyes.

Another species, Munidopsis myojinensis was collected from the Myojin Knoll (1200m depth) in the Izu-Ogasawara Arc (Fig. 10d). They did not gather together around the hot water vent inlet in the tank. This species also did not feed on krill or other meat. Individuals of this species died after a short period of rearing in a non-vent tank, but in the vent tank this species lived over a long period. This suggests that $M$. myojinensis may eat the bacterial mats around hydrothermal vents. However, in order to clarify whether their vent-dependence is due to food or some other factor, we need to do further experiments using the stable isotope tracer method, etc. Some specimens were brooding eggs when they were collected. Eggs were $2 \mathrm{~mm}$ in diameter and were reddish-orange in color. They were attached to the pleopods of females. Some eggs collected from females were kept in petri dishes with temperature controlled to remain at $4^{\circ} \mathrm{C}$. Eggs were not positively buoyant but larvae just after hatching floated towards the surface (Fig. 10e).

\subsection{Vestimentiferan tubeworms}

The vestimentiferan tubeworms we have attempted to rear include Lamellibrachia sp. collected from Sagami Bay $(850 \mathrm{~m})$, and Lamellibrachia satsuma collected from Kagoshima Bay $(80 \sim 110 \mathrm{~m})$ and Nikko seamount $(450 \mathrm{~m})$ in the Izu-Ogasawara Arc. Tubeworms were kept in an improved cold seep tank. There is no DO controller and also no addition of $\mathrm{Na}_{2} \mathrm{~S}$ for making $\mathrm{H}_{2} \mathrm{~S}$ in this rearing tank. Mud collected from Ariake Bay was mixed with dog food and laid on the bottom of the tank at a thickness of 5-10 cm. Then mud from Ariake Bay was overlaid to a thickness of $10 \mathrm{~cm}$ on top of the dogfood-mud mixture. Hydrogen sulfide, methane and ammonia for growth of the tubeworms were generated from the rotten dog food in the mud. When the dog food went rotten, large amounts of oxygen were consumed. This decreased the levels of dissolved oxygen in the tank. Carbon dioxide was added as a source of carbon for chemoautotrophic symbiotic bacteria. The $\mathrm{pH}$ was maintained at low levels $(\sim 6.8-7.0)$ by bubbling carbon dioxide using a $\mathrm{pH}$ controller. When the $\mathrm{pH}$ is high $(>7.0)$, an electro-magnetic valve connected to the $\mathrm{pH}$ controller automatically opens and $\mathrm{CO}_{2}$ input starts. When the $\mathrm{pH}$ is low $(<6.8)$, the valve closes and $\mathrm{CO}_{2}$ input stops. When the improved cold seep tank was running well, bacterial mats emerged on the surface of the mud.

If tubeworms are collected in good condition with no injuries, long-term rearing is quite easy. Tubeworms in situ extend their gills from the upper opening of the tube (Fig. 11a). Tubeworms in high dissolved oxygen conditions have a tendency to keep their gills within their tube. However, tubeworms in low dissolved oxygen conditions extend their gills from their tubes. Tubeworms were unable to survive in a completely anaerobic environment. The growth of the tube was faster in low oxygen and high carbon dioxide conditions than in any other combination of conditions.

A few days after sampling of tubeworms, fertilized eggs were collected by filtration of the rearing tank seawater using a $100 \mu \mathrm{m}$ mesh net or by dissection of the tubeworm egg 
pouches. Larvae developed to trochophores just before the settlement stage (Fig. 11b). However, we were unable to observe metamorphosis of trochophore larvae into juvenile tube-worms. Shinozaki et al. (2010) reported reproduction of Lamellibrachia satsuma in the aquarium. This strain of L. satsuma inhabited a whalebone substrate. Whalebones are an energy and nutrient source for both L. satsuma and its symbionts. Keeping tubeworms over the long-term can be accomplished using whalebones, but a combination of whalebones and mud would probably be better for rearing cold seep species. However, water quality must be carefully monitored because of the large amount of rotten organic matter contained within whalebones.

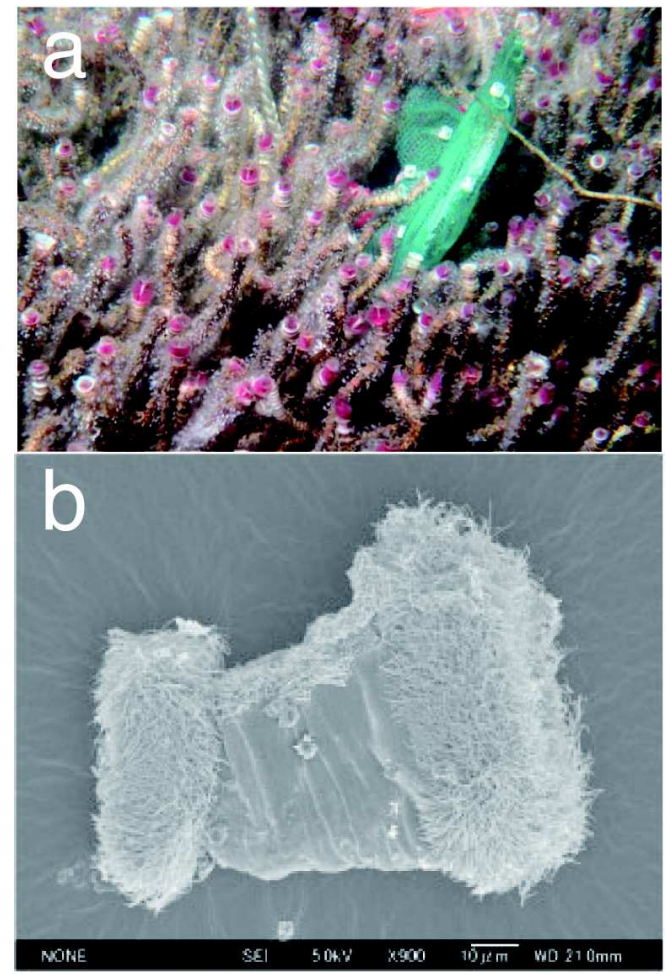

Fig. 11. Lamellibrachia satsuma

\subsection{Deep-sea white clams}

The giant white clams Calyptogena okutanii and C. soyoae were collected from cold seeps off Hatsushima, Sagami Bay $(850 \mathrm{~m})$ and C. kawamutai were collected from a cold seep at Kuroshima Knoll, off Ishigaki Island $(600 \mathrm{~m})$ using scoops, sample boxes, and MT core samplers. Calyptogena clams have been very difficult to keep. Before using an MT core for sampling, we were only able to keep C. soyoae alive for a few days. Using an MT core to collect the clam and its microenvironment simultaneously allowed us to keep C. okutanii and C. soyoae alive for a week, and C. kawamurai for 17 days. Spawning of $C$. solidissima has been observed on two occasions during their captivity in aquaria (Miyake et al., 2005). 
Calyptogena okutanii has now been kept successfully for two months in the mud in the cold seep area of the deep-sea chemosynthetic ecosystem tank (Fig. 12).

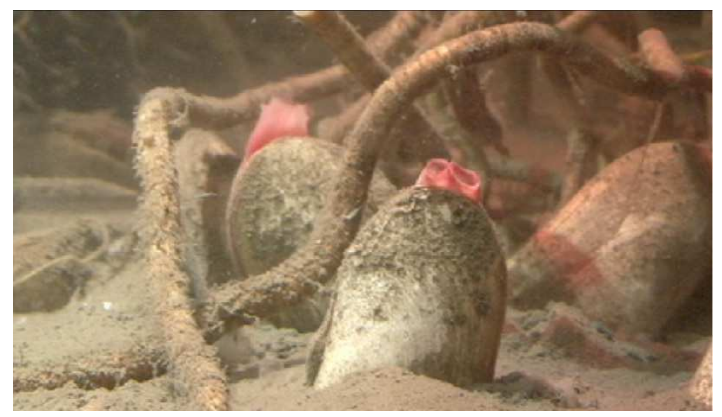

Fig. 12 Calyptogena okutanii at artificial cold seep area of Chemosynthetic ecosystem tank

Dissolved oxygen was needed for the Calyptoena clam itself, but a low dissolved oxygen environment was needed for the symbiotic chemosynthetic bacteria to allow them to use hydrogen sulfide. Therefore, it is essential to make a gradient in the dissolved oxygen concentration so that the deeper layer of mud is an anaerobic environment and the surface layer of mud and the bottom water layer are aerobic environments. This, in principle, is the same for tubeworm from cold seeps.

\subsection{Fishes from chemosynthesis-based ecosystems}

Some zoarcid fish were collected from cold seeps in Sagami Bay and hydrothermal vent areas in the Okinawa Trough using a suction sampler without needing to keep pressure at ambient deep-sea levels. The species of zoarcid fishes were Ericandersonia sagamia (Fig. 13a), Japonolycodes abei, a snake-like undescribed species, and some other undescribed species (Fig. 13b, c). Zoarcid fishes collected from the deep sea were damaged during retrieval to the ship's deck because of the drastic change in pressure and temperature. After one night, almost all the specimens stayed on the bottom of the aquarium. They slowly began to feed on krill or mysids over the course of a week. The rearing method we used for zoarcid fish was the same as we use for normal deep-sea fish. Although they were collected from cold seep areas, they are unable to endure the hydrogen sulfide-rich environment that Shinkaia crosnieri needs to farm bacterial filaments on its ventral hairs.

The snake-like undescribed fish spawned in the aquarium. This fish was a batch-spawner that spawns large eggs. A female raised 27 eggs at a time in one egg batch. However, the eggs were not fertilized. Eggs were about $5 \sim 6 \mathrm{~mm}$ in diameter, were white in color and were positively buoyant (Fig. 13d). The zoarcid fishes, Lycodes cortezianzus and Lycodapus mandibularis, however, laid eggs that were negatively buoyant (Ferry-Graham et al., 2007). This species has been found within a vestimentiferan tube-worm (Alaysia sp.) colony, a Bathmodiolus mussel colony and a Calyptogena clam colony at cold seeps off Hatsushima, Sagami Bay. This species may lay egg batches in spaces within these colonies, e.g. in the tubeworm bush or between mussels, so as they do not rise up into the water column. 


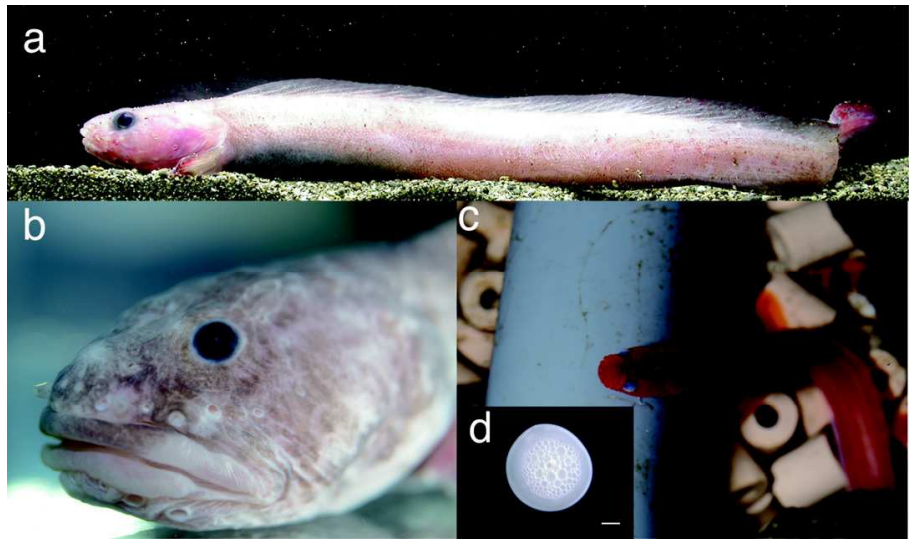

Fig. 13. Zoarcid fishes.

The vent tonguefish Symphurus thermophiles is also one fish that can be sampled successfully without keeping pressure at ambient levels (Fig. 14a). This species was collected from the Nikko seamount $(450 \mathrm{~m})$ in the Izu-Ogasawara Arc. This species can also be kept in a normal aquarium as well as in the hydrothermal vent tank. S. thermophiles was usually either on the sand, hidden in the sand, or sometimes on the walls of the tank. S. thermophiles fed on any food that was dropped in front of them, especially when the food item was moving. It is supposed that, although this species inhabits deep-sea hydrothermal vent areas at depths of $400 \sim 500 \mathrm{~m}$, this species finds prey items by vision.

S. thermophilis spawned in the tank. Mating occurred at approximately $30 \mathrm{~cm}$ above the bottom by close swimming between females and males in the aquarium. Eggs were positively buoyant, were transparent, and were approximately $1 \mathrm{~mm}$ in diameter (Fig. 14b). Larvae just after hatching had yolk sacs and did not have eyes or gastro- intestinal tracts (Fig. 14c). Three days after hatching, the development of the gastrointestinal tract was complete. One week after hatching, eyes and a mouth had developed and larvae could prey on small plankton.

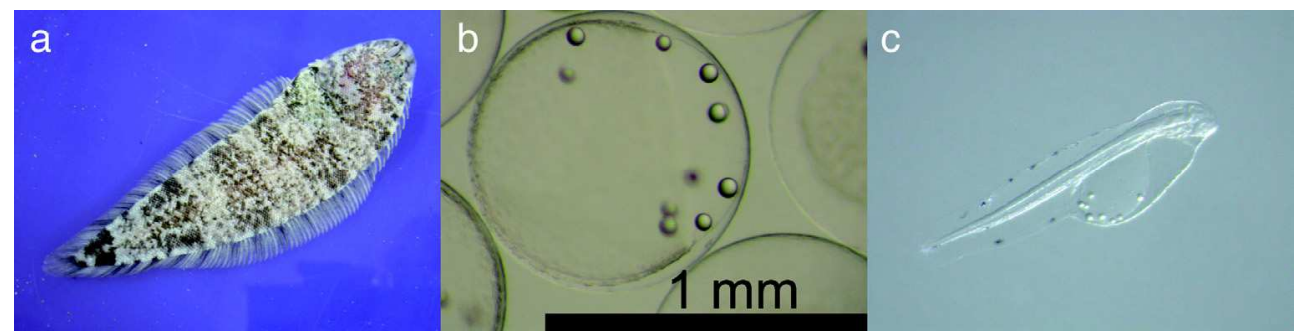

Fig. 14. Symphurus thermophiles

\section{Summary and future studies}

Recently studies on deep-sea animals using rearing methods such as those outlined above have been increasing. Mid-water hydromedusae have been raised from polyps collected 
from artificial substrates set on the deep-sea floor, from the bodies of mid-water shrimp, and by artificial fertilization, thereafter being described as new species (Widmer, 2007; Widmer et al., 2010; Widmer, 2011). Some other hydropolyps and scyphopolyps collected from deepsea litter have been kept in the laboratory at Kitasato University, and a few species of them may be undescribed species according to preliminary identifications from morphology and genetics. The collection of deep-sea litter is a highly efficient way to find deep-sea sessile organisms, including jellyfish polyps. As for animals in chemosynthetic-based ecosystems, a hydrothermal vent barnacle, Neoverruca sp. (Watanabe et al., 2004), and hydrothermal vent crabs such as Bythograea thermydron (Epifanio et al., 1999; Jinks et al., 2002; Dittel et al., 2008) and Gandalfus yunohana (Hamasaki et al., 2010) have been kept for long periods. In particular, Gandalfus yunohana was observed during growth from eggs to juveniles at various temperatures. These data are very important to understand the larval ecology of vent animals and could not be obtained by in situ observations from submersibles. Whalebones are also useful for successfully keeping vent and seep animals in aquaria. The whale-fall mussel Adipicola pacifica (Fujiwara et al., 2010; Kinoshita et al., 2010) and the vestimentiferen tubeworm Lamellibrachia satsuma (Shinozaki et al., 2010), which were found attached to whalebones in situ, have been kept successfully in aquaria without adding nutrients or energy sources such as hydrogen sulfide, carbon dioxide, anmonia etc. Moreover, L. satsuma that was attached to a whalebone spawned in the aquarium and newly-settled individuals also appeared on this whalebone. The vent mussel Bathymodiolus azoricus (Kadar et al., 2005; Kadar et al., 2006; Kadar et al., 2009; Bettencourt et al., 2010; Bettencourt et al., 2011) and the thermophilic worm Alvinella pompejana (Pradillon et al., 2001; Pradillon et al., 2004; Pradillon et al., 2005) were kept at atmospheric pressure and in situ pressure using a pressurized tank and were studied immunologically, histologically, developmentally, and behaviorally. A pressurized tank may allow the rearing of deep-sea animals that cannot be collected alive at atmospheric pressure and also allow studies without the bias of different pressure regimes. Behavioral responses towards heat have been studied for the hydrothermal vent polychaete Hesiolyra bergi by IPOCAMP (Shillito et al., 2001). The developmental biology of the vestimentiferan tubeworm Riftia pachyptila has been studied in pressure vessels (Marsh et al., 2001; Brooke \& Young, 2009). The vent shrimp, Alvinocaris sp. and the deep-sea eel, Simenchelys parasiticus have also been collected by the DEEP AQUARIUM system without serious damage sustained by decompression and/or exposure to the high temperatures of surface seawater (Koyama et al., 2005; Koyama, 2007).

A new pressurized recovery device, PERISCOP, has recently been developed (Shillito et al., 2008). Now we have some techniques to collect and rear deep-sea animals at atomospheric pressure, and we can also collect and keep deep-sea animals in pressure-retained aquarium systems and decrease pressure slowly to atmospheric pressure to acclimatize the animals to atmospheric pressure. It is essential to try and improve communication and technology exchanges between scientists and technicians working on rearing techniques for deep-sea animals in order for us to successfully complete life cycles and make important observations on these enigmatic organisms.

Rearing of deep-sea animals allows scientists to observe the behaviors and modes of life of these animals just as if they were in situ and it also allows scientists to do various experiments in the laboratory. This is an important breakthrough in biological studies of deep-sea animals. Additionally, displaying and rearing deep-sea animals allows the public 
to watch mysterious and curious "live" deep-sea animals without having to go on deep-sea survey missions personally and it lets us introduce deep-sea biology to the public in an easy-to-understand manner.

\section{Acknowledgments}

We sincerely thank the captains and crews of the R/V Natsushima, R/V Kaiyo and R/V Yokosuka and the commanders, pilots, and operations teams of the ROVs Dolphin-3K and Hyper-Dolphin and the crewed submersibles Shinkai 2000 and Shinkai 6500 for their dedicated efforts. We also thank Mrs. Yukiko Hori, the Director of the Enoshima Aquarium, and Dr. Tadashi Maruyama, the Program Director of the Marine Biodiversity Research Program, Institute of Biogeoscience, JAMSTEC, for their encouragement to us. Finally, thanks are due to many colleagues for their active support aboard ships, for laboratory assistance and for other kinds of help they have graciously provided.

\section{References}

Bettencourt R., V. Costa, M. Laranjo, D. Rosa, L. Pires, A. Colaco, H. Lopes \& R.S. Santos. (2011). Out of the deep sea into a land-based aquarium environment: Investigating physiological adaptations in the hydrothermal vent mussel Bathymodiolus azoricus. ICES Journal of Marine Science, Vol.68. No.2: 357-364.

Bettencourt R., V. Costa, M. Laranjo, D. Rosa, L. Pires, A. Colaco, P.M. Sarradin, H. Lopes, M.J. Sarrazin \& R.S. Santos. (2010). Out of the deep-sea into a land-based aquarium environment: Investigating innate immunity in the hydrothermal vent mussel $\mathrm{i}$. Cahiers de Biologie Marine, Vol.51. No.4: 341-350.

Brooke S.D. \& C.M. Young. (2009). Where do the embryos of Riftia pachyptila develop? Pressure tolerances, temperature tolerances, and buoyancy during prolonged embryonic dispersal. Deep-Sea Research Part Ii-Topical Studies in Oceanography, Vol.56. No.19-20: 1599-1606.

Corliss J.B. \& R.D. Ballard. (1977). Oases of life in the cold abyss. National Geographic Magazine, Vol.152. 441-453.

Corliss J.B., J. Dymond, L. Gordo, J.M. Edomond, R.P.v. Herzen, R.D. Ballard, K. Green, D. Williams, A. Bainbridge, K. Crane \& T.H.v. Andel. (1979). Submersible thermal springs on the galapagos rift. Science, Vol.203. No.1073-1083.

Dittel A.I., G. Perovich\&C.E. Epifanio. (2008). Biology of the vent crab Bythograea thermydron: A brief review. Journal of Shellfish Research, Vol.27. No.1: 63-77.

Epifanio C.E., G. Perovich, A.I. Dittel \& S.C. Cary. (1999). Development and behavior of megalopa larvae and juveniles of the hydrothermal vent crab Bythograea thermydron. Marine Ecology Progress Series, Vol.185. 147-154.

Ferry-Graham L.A., J.C. Drazen \& V. Franklin. (2007). Laboratory observations of reproduction in the deep-water zoarcids Lycodes cortezianzus and Lycodapus mandibularis (Teleostei : Zoarcidae). Pacific Science, Vol.61. No.1: 129-139.

Fujikura K., T. Okutani \& T. Maruyama. (2008). Deep-sea life - biological observations using research submersibles. Tokai University Press

Fujiwara Y., G. Kinoshita, M. Kawato, A. Shinozaki, T. Yamamoto, K. Okoshi, K. Kubokawa \& H. Yamamoto. (2010). Protandric hermaphroditism in the whale-fall mussel Adipicola pacifica. Cahiers de Biologie Marine, Vol.51. No.4: 423-427. 
Gage J.D. \& P.A. Tyler. (1991). Deep-sea biology: A natural history of organisms at the deep-sea floor. Cambridge University Press, New York

Hamasaki K., K. Nakajima, S. Tsuchida, R. Kado \& S. Kitada. (2010). Number and duration of zoeal stages of the hydrothermal vent crab Gandalfus yunohana from laboratory reared specimens. Journal of Crustacean Biology, Vol.30. No.2: 236-240.

Hamner W.M. (1990). Design developments in the planktonkreisel, a plankton aquarium for ships at sea. Jouenal of Plankton Research, Vol.12. No.2: 393-402.

Hashimoto J., K. Fujikura, T. Aoki \& S. Tsukioka. (1992). Development of a suction sampler (slurp gun) for deep sea organisms. Proc. JAMSTEC Symp. Deep Sea Res., Vol.8. 367372.

Herring P.J. (1972). Porphyrin pigmentation in deep-sea medusae. Nature, Vol.238. 276.

Herring P.J (2002). The biology of the deep ocean. Oxford University Press, New York

Herring P.J., P. Gatent \& P.M.J. Shelton. (1999). Are vent shrimps blinded by science? Nature, Vol.398. 1116.

Hunt J.C., J. Hashimoto, Y. Fujiwara, D.J. Lindsay, K. Fujikura, S. Tsuchida \& T. Yamamoto. (1997). The development, implementation, and establishment of a meso-pelagic and bentho-pelagic biological survey program using submersibles in the seas around japan. JAMSTEC J. Deep Sea Research, Vol.13. 675-685.

Jinks R.N., T.L. Markley, E.E. Taylor, G. Perovich, A.I. Dittel, C.E. Epifanio \& T.W. Cronin. (2002). Adaptive visual metamorphosis in a deep-sea hydrothermal vent crab. Nature, Vol.420. No.6911: 68-70.

Kadar E., R. Bettencourt, V. Costa, R.S. Santos, A. Lobo-Da-Cunha \& P. Dando. (2005). Experimentally induced endosymbiont loss and re-acquirement in the hydrothermal vent bivalve Bathymodiolus azoricus. Journal of Experimental Marine Biology and Ecology, Vol.318. No.1: 99-110.

Kadar E., A. Lobo-da-Cunha\&C. Azevedo. (2009). Mantle-to-shell CaCo3 transfer during shell repair at different hydrostatic pressures in the deep-sea vent mussel Bathymodiolus azoricus; (Bivalvia: Mytilidae). Marine Biology, Vol.156. No.5: 959-967.

Kadar E., A. Lobo-Da-Cunha, R.S. Santos \& P. Dando. (2006). Spermatogenesis of Bathymodiolus azoricus in captivity matching reproductive behaviour at deep-sea hydrothermal vents. Journal of Experimental Marine Biology and Ecology, Vol.335. No.1: 19-26.

Kinoshita G., M. Kawato, A. Shinozaki, T. Yamamoto, K. Okoshi, K. Kubokawa, H. Yamamoto \& Y. Fujiwara. (2010). Protandric hermaphroditism in the whale-fall mussel Adipicola pacifica. Cahiers de Biologie Marine, Vol.51. No.4: 423-427.

Koyama S. (2007). Cell biology of deep-sea multicellular organisms. Cytotechnology, Vol.55. No.2-3: 125-133.

Koyama S., T. Miwa, M. Horii, Y. Ishikawa, K. Horikoshi \& M. Aizawa. (2002). Pressure-stat aquarium system designed for capturing and maintaining deep-sea organisms. Deep-Sea Research Part I-Oceanographic Research Papers, Vol.49. No.11: 2095-2102.

Koyama S., T. Nagahama, N. Ootsu, T. Takayama, M. Horii, S. Konishi, T. Miwa, Y. Ishikawa \& M. Aizawa. (2005). Survival of deep-sea shrimp (Alvinocaris sp.) during decompression and larval hatching at atmospheric pressure. Marine Biotechnology, Vol.7. No.4: 272-278. 
Marsh A.G., L.S. Mullineaux, C.M. Young \& D.T. Manahan. (2001). Larval dispersal potential of the tubeworm Riftia pachyptila at deep-sea hydrothermal vents. Nature, Vol.411. No.6833: 77-80.

Miyake H., M. Kitada, S. Tsuchida, Y. Okuyama \& K. Nakamura. (2007). Ecological aspects of hydrothermal vent animals in captivity at atmospheric pressure. Marine Ecologyan Evolutionary Perspective, Vol.28. No.1: 86-92.

Miyake H., D.J. Lindsay \& J.C. Hunt. (2001). The study of gelatinous zooplankton using submersibles and ROVs. Kaiyo Monthly, Vol. Extra edition 27. 216-223.

Miyake H., J. Tsukahara, J. Hashimoto, K. Uematsu \& T. Maruyama. (2006). Rearing and observation methods of vestimentiferan tubeworm and its early development at atmospheric pressure. Cahiers de Biologie Marine, Vol.47. No.4: 471-475.

Matsuyama \& S., H. Yamamoto, M. Kitada, I. Ueda, K. Okoshi, M. Kitamura, K. Matsuyama\&S. Tsuchida. (2005). Attempts to rear the deep-sea white clams calyptogena soyoae and calyptogena solidissima. Oceanography $i$ i Japan, Vol.14. No.6: 645-651.

Paull C.K., B. Hecker, R. Commeau, R.P. Freeman-Lynde, C. Neumann, W.P. Corso, S. Golubic, J.E. Hook, E. Sikes \& J. Curray. (1984). Biological communities at the florida escarpment resemble hydrothermal vent taxa. Science, Vol.226. No.965-967.

Pradillon F., N. Le Bris, B. Shillito, C.M. Young \& F. Gaill. (2005). Influence of environmental conditions on early development of the hydrothermal vent polychaete Alvinella pompejana. Journal of Experimental Biology, Vol.208. No.8: 1551-1561.

Pradillon F., B. Shillito, J.C. Chervin, G. Hamel \& F. Gaill. (2004). Pressure vessels for in vivo studies of deep-sea fauna. High Pressure Research, Vol.24. No.2: 237-246.

Pradillon F., B. Shillito, C.M. Young \& F. Gaill. (2001). Deep-sea ecology. Developmental arrest in vent worm embryos. Nature, Vol.413. 698-699.

Raskoff K., F.A. Sommer, W.M. Hamner \& K.M. Cross. (2003). Collection and culture techniques for gelatinous zooplankton. Biological Bulletin, Vol.204. 68-80.

Robison B.H. (2004). Deep pelagic biology. Journal of Experimental Marine Biology and Ecology, Vol.300. 253-272.

Shillito B., G. Hamel, C. Duchi, D. Cottin, J. Sarrazin, P.M. Sarradin, J. Ravaux \& F. Gaill. (2008). Live capture of megafauna from $2300 \mathrm{~m}$ depth, using a newly designed pressurized recovery device. Deep-Sea Research Part I-Oceanographic Research Papers, Vol.55. No.7: 881-889.

Shillito B., D. Jollivet, P.M. Sarradin, P. Rodier, F. Lallier, D. Desbruyeres \& F. Gaill. (2001). Temperature resistance of Hesiolyra bergi, a polychaetous annelid living on deep-sea vent smoker walls. Marine Ecology-Progress Series, Vol.216. 141-149.

Shinozaki A., M. Kawato, C. Noda, T. Yamamoto, K. Kubokawa, T. Yamanaka, J. Tahara, H. Nakajoh, T. Aoki, H. Miyake \& Y. Fujiwara. (2010). Reproduction of the vestimentiferan tubeworm Lamellibrachia satsuma inhabiting a whale vertebra in an aquarium. Cahiers de Biologie Marine, Vol.51. No.4: 467-473.

Smith C.R., H. Kukert, R.A. Wheatcroft, P.A. Jumars \& J.W. Deming. (1989). Vent fauna on whale remains. Nature, Vol. 341. 27-28.

Van Dover C.L. (2000). The ecology of deep-sea hydrothermal vents. Princeton University Press, Princeton

Watanabe H., R. Kado, S. Tsuchida, H. Miyake, M. Kyo \& S. Kojima. (2004). Larval development and intermoult period of the hydrothermal vent barnacle Neoverruca 
sp. Journal of the Marine Biological Association of the United Kingdom, Vol.84. No.4: 743-745.

Widmer C.L. (2007). The hydroid and medusa of Amphinema rollinsi (Cnidaria : Hydrozoa), a new species of pandeid from the Monterey Bay submarine canyon, USA. Zootaxa. No.1595: 53-59.

Widmer C.L. (2008). How to keep jellyfish in aquariums: An introductory guide for maintaining healthy jellies. Wheatmark, 978-1-60494-126-5, Tucson, Arizona

Widmer C.L. (2011). The hydroid and early medusa stages of the deep sea jellyfish Earleria purpurea (Hydrozoa: Mitrocomidae) from the Monterey Bay submarine canyon, USA. Zootaxa. No.2902: 59-68.

Widmer C.L., G. Cailliet\&J. Geller. (2010). The life cycle of Earleria corachloeae n. sp (Cnidaria: Hydrozoa) with epibiotic hydroids on mid-water shrimp. Marine Biology, Vol.157. No.1: 49-58. 


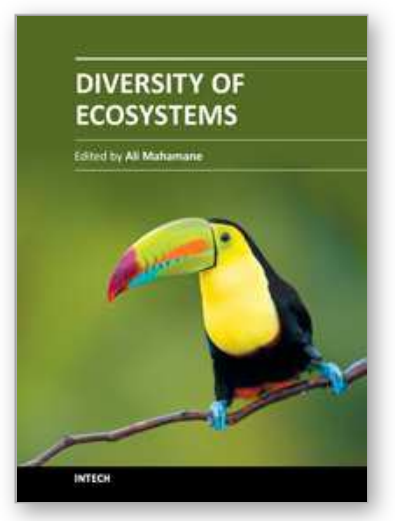

\author{
Diversity of Ecosystems \\ Edited by Prof. Mahamane Ali
}

ISBN 978-953-51-0572-5

Hard cover, 484 pages

Publisher InTech

Published online 27, April, 2012

Published in print edition April, 2012

The ecosystems present a great diversity worldwide and use various functionalities according to ecologic regions. In this new context of variability and climatic changes, these ecosystems undergo notable modifications amplified by domestic uses of which it was subjected to. Indeed the ecosystems render diverse services to humanity from their composition and structure but the tolerable levels are unknown. The preservation of these ecosystemic services needs a clear understanding of their complexity. The role of research is not only to characterise the ecosystems but also to clearly define the tolerable usage levels. Their characterisation proves to be important not only for the local populations that use it but also for the conservation of biodiversity. Hence, the measurement, management and protection of ecosystems need innovative and diverse methods. For all these reasons, the aim of this book is to bring out a general view on the function of ecosystems, modelling, sampling strategies, invading species, the response of organisms to modifications, the carbon dynamics, the mathematical models and theories that can be applied in diverse conditions.

\title{
How to reference
}

In order to correctly reference this scholarly work, feel free to copy and paste the following:

Hiroshi Miyake, Mitsugu Kitada, Dhugal J. Lindsay, Toshishige Itoh, Suguru Nemoto and Tetsuya Miwa (2012). How to Keep Deep-Sea Animals, Diversity of Ecosystems, Prof. Mahamane Ali (Ed.), ISBN: 978-953-51-05725, InTech, Available from: http://www.intechopen.com/books/diversity-of-ecosystems/how-to-keep-deep-seaanimals

\section{INTECH}

open science | open minds

\section{InTech Europe}

University Campus STeP Ri

Slavka Krautzeka 83/A

51000 Rijeka, Croatia

Phone: +385 (51) 770447

Fax: +385 (51) 686166

www.intechopen.com

\section{InTech China}

Unit 405, Office Block, Hotel Equatorial Shanghai

No.65, Yan An Road (West), Shanghai, 200040, China 中国上海市延安西路65号上海国际贵都大饭店办公楼 405 单元

Phone: $+86-21-62489820$

Fax: +86-21-62489821 
(C) 2012 The Author(s). Licensee IntechOpen. This is an open access article distributed under the terms of the Creative Commons Attribution 3.0 License, which permits unrestricted use, distribution, and reproduction in any medium, provided the original work is properly cited. 